\title{
Oil and Gas Balance Analysis (Case Study of "X" Field)
}

\author{
Ramli Nonci ${ }^{*}$, Akhmad Fauzi, Fifi Diana Thamrin \\ Department of Natural Resources and Environment Economic, Faculty of Economic \& Management, IPB University, Bogor, Indonesia
}

Email address:

nonci2003@gmail.com (R. Nonci)

${ }^{*}$ Corresponding author

\section{To cite this article:}

Ramli Nonci, Akhmad Fauzi, Fifi Diana Thamrin, Oil and Gas Balance Analysis (Case Study of "X" Field). Journal of Business and Economic Development. Vol. 5, No. 3, 2020, pp. 121-129. doi: 10.11648/j.jbed.20200503.12

Received: June 13, 2020; Accepted: June 23, 2020; Published: July 13, 2020

\begin{abstract}
Indonesia is one of the countries in the world that has the potential of natural resources in the form of oil and gas. As a resource that plays an important role in economic life, the utilization of oil and gas needs to be managed properly and correctly. Preparation of the balance of natural resources is an important part of the management of wealth controlled by the state. The value of resources must be known so that the government can make the right policies, especially for oil and gas fields that will be terminated. One of the oil and gas resources which has significant production value and impact on the Indonesian economy is the "X" field in East Kalimantan. This study aims to provide an overview of oil and gas processing in the "X" field, estimate the monetary value of oil and gas volumes in a certain period and analyze policies that can encourage the management of the remaining oil and gas fields more optimally. The data used in the research are sourced from the results of discussions, field observations, studies of government policy literature, and company documentation. The analysis conducted in this study is divided into description analysis, oil and gas balance analysis and policy analysis. The analytical tools used are a study of government and company policy literature, the Net Present Value (NVP) method and the Multi Criteria Decision Analysis (MCDA) method. Based on the analysis, the physical value of proven oil and gas reserves in the " $\mathrm{X}$ " field amounted to $322,988,294$ barrels \& 420,745,986 MSCF; while the monetary value of oil and gas reserves amounting to IDR 222.655.210.375.641 (oil) and IDR 722,623,266,696 (gas) until 2018. Analysis of policies for the development of the "X" field taking into account economic, social and HSE (Health, Safety and Environmental) criteria results in a conclusion that Gross Split policy alternatives have the highest value for the draft of as business as usual policy when compared to the Cost Recovery policy and the Cost and Fee policy.
\end{abstract}

Keywords: Oil and Gas, Physical and Monetary Balance, NVP, Multi Criteria Decision Analysis, Policy

\section{Introduction}

In the history of national development in Indonesia, oil and natural gas have an important and strategic role. Oil and natural gas are also sources of energy for national economic activities. The oil and gas sector also contributes to state revenue sourced from oil and gas management.

Oil and gas mining take thousands or even millions of years to form because of the inability of these resources to regenerate (non-renewable). These natural resources are often called natural resources that have a fixed stock [8]. The national petroleum industry is old, more than 100 years old, and its production is declining. Throughout the history of the independent Republic of Indonesia, oil production peaks occurred twice, namely in 1977 and 1995 where petroleum production amounted to 1.68 million bpd and 1.62 million bpd, respectively. After 1995 Indonesia's average oil production declined with a natural decline rate of around $12 \%$ per year. However, since 2004 the decline in oil production can be held with a decline rate of around 3\% per year.

The Oil and Gas Sector is a technology and capital laden sector, the Republic of Indonesia's oil and gas industry is very dependent on investors (especially foreign). Profit sharing is carried out based on profit sharing, commonly referred to as a Production Sharing Contract (PSC). In its journey, the PSC always uses the cost recovery (CR) method and is carried out downstream with the sharing of government revenue sharing with the controller being $85 \%$ : 15\% (oil) and 70\%: $30 \%$ (gas) after the cost recovery is paid by the government and its components the other. In new oil 
and gas contracts (not existing) they no longer use CR but with Gross Split (GS) where the distribution of costs and profits is made up front which can be adjusted based on variable components $(\mathrm{KV})$ and progressive components (KP). The amount of the initial share (base spill) for Petroleum is $57 \%$ for the State and $43 \%$ for the Contractor and for Natural Gas $52 \%$ for the State and $48 \%$ for the Contractor. Another alternative method is Cost and Fee $(\mathrm{CF})$ where the contractor becomes compensation in the form of a Fee from each Recoverable Cost that is issued.

Environmental Protection and Management Law Number 32 Year 2009 of the Republic of Indonesia explains that natural and environmental resource balance sheets need to be prepared by all governments both at the national and regional levels. Study conducted of oil and gas resources by making a physical balance of oil and gas during the certain period using the Net Present Value method [12].

Considering the importance of oil and gas production in the " $\mathrm{X}$ " field to support national energy security, the researchers considered it important to conduct research on the fair value of oil and gas reserves in the field. The fair value of oil and gas reserves (Stock) is one of the factors (criteria) in conducting a policy analysis of the management of oil and gas resources to determine the best alternative policy model among the Cost Recovery (CR), Gross Split (GS) and Cost and Fee models by using Multi Criteria Decision Analysis (MCDA). MCDA used in determining the best method to be used in enhanced oil recovery (EOR) techniques [15].

The specific objectives of this study are as follows: (1) Estimating the monetary value of oil and gas volume preparations (2) Providing management recommendations so that the utilization of the remaining oil and gas is more optimal.

\section{Research Methodology}

This research was conducted at "X" Field, East Kalimantan Province. The location selection was carried out deliberately (purposive) with the consideration that the Field as the main supplier of oil and gas for the Eastern Indonesia region. The secondary data collection is carried out from March to August 2019.

The type of data used in this study is cross section data. Data sources include primary data and secondary data. Primary data obtained through the interview process with respondents from key person. Secondary data sources obtained from scientific journals, related agency reports, data already available from related companies in the form of documentary data, as well as various previous studies related to this research.
Monetary balance can be calculated by multiplying physical balance with unit rent. How to calculate oil and gas resource unit rent using the Net Present Value (NPV) method. The Net Present Value (NPV) method is the process of calculating the value of resources using the price of these resources as the value of future sales, less the costs of exploitation. To calculate the NPV it is necessary to calculate the estimated age of oil and gas reserves for future returns. The calculation formula used is:

$$
\begin{gathered}
P V=\sum_{t=1}^{T} \frac{F V_{t}}{(1+r)^{t}} \\
P V=\sum_{t=1}^{T} \frac{N_{t} Q_{t}}{(1+r)^{t}} \\
\text { Unit Rent }_{t}=\frac{P V}{\text { Reserves }_{t}}
\end{gathered}
$$

Where: $P V=$ Present value of a natural resource (IDR), $F V t=$ future value of a natural resource (IDR), $N t=$ value of natural resources minus exploitation costs for the t-year (IDR / barrel), $Q t=$ volume exploited in the t-year year (barrel), $T=$ year, $t=$ age of natural resource, $r=$ interest rate.

\subsection{Policy Analysis}

Problems with these various criteria can be solved by using the multi-criteria decision analysis (MCDA) method with the Technique for Order Preference by Similarity to Ideal Solution (TOPSIS) approach. The steps used in using the TOPSIS approach are as following [33].

\subsubsection{Construct a Decision Matrix}

Assume there are a number of alternative m $A i(i=1,2, \ldots, m)$ which will be evaluated against a number of n criteria $C j(j=1$, $2, \ldots, n)$.

Subjective assessment results from decision makers in determining the weight vector $W=(w 1, w 2, \ldots, w j, \ldots w j)$. The vector weight $(\mathrm{W})$ represents the relative importance of the $n$ criteria $C j(j=1,2, \ldots, n)$ in decision making. The decision matrix can be displayed in the following presentation:

$$
\begin{aligned}
& C 1 C 2 \ldots C n \\
& D=\begin{array}{c}
A 1 \\
A 2 \\
\cdots \\
A m
\end{array}\left[\begin{array}{cccc}
X 11 & X 12 & \ldots & X 1 n \\
X 21 & X 22 & \ldots & X 2 n \\
\vdots & \vdots & \ddots & \ldots \\
X m 1 & X m 2 & \cdots & X m n
\end{array}\right] \\
& W i=W 1, W 2, \ldots W n
\end{aligned}
$$

The criteria and sub-criteria used in the analysis of the "X" field management policy are shown in Table 1.

\subsection{Monetary and Physical Balance}

Table 1. Criteria and sub-criteria in research.

\begin{tabular}{llll}
\hline Criteria & Sub Criteria & Unit & Criteria description \\
\hline Economic & Government of Indonesia (GOI) & $\%$ & Profit sharing to the Indonesian government \\
$($ EKO) & Contractor partnership contract (K3S) & $\%$ & Profit sharing of the contractor \\
\hline
\end{tabular}




\begin{tabular}{llll}
\hline Criteria & Sub Criteria & Unit & Criteria description \\
\hline & Progressive Component (KP) \& Variable Component (KV) & $\%$ & Additional components to the contractor \\
& Price (HG) & IDR/barrel & Crude oil price \\
& Lifting cost (BY) & IDR/barrel & Production costs for each barrel of oil in "X" field \\
& Reserves (Stock) & barrel & Reserve of Petroleum resources preserved by "X" field \\
Social (SOS) & Labor (TK) & Person & Total labor supply \\
$\begin{array}{l}\text { Health, Safety } \\
\text { and }\end{array}$ & Health (H) & & Health policy management \\
$\begin{array}{l}\text { Environment } \\
\text { (HSE) }\end{array}$ & Safety (S) & Scala Likert & Safety policy management \\
\hline
\end{tabular}

\subsubsection{Calculate The Normalized Decision Matrix}

The projected value of each criterion can be generated from the calculation of a normalized decision matrix. The equation used in calculating the normalized decision matrix is as follows;

$$
n_{i j}=\frac{x i j}{\sqrt{\sum_{i}^{m} x_{i j}^{2}}} ; i=1, \ldots,=1, \ldots n ;
$$

\subsubsection{Calculating The Weighted Normal Decision Matrix}

The weighted normal decision matrix calculation $(V i j)$ uses the following equation;

$$
V_{i j}=W_{j} n_{i j}, i=1, \ldots, m ; j=1, \ldots n
$$

Wwhere is the weight of the $\mathrm{j}$-th criteria and the sum of the overall weights is 1 ,

$$
\left(\sum_{j=1}^{n} W j=1\right)
$$

\subsubsection{Determination of Positive Ideal Solutions $(A+)$ and Negative Ideal Solutions $\left(A^{-}\right)$}

The calculation used to get the positive ideal solution $(A+)$ and the negative ideal solution $\left(A^{-}\right)$uses the following equation;

$$
\begin{aligned}
& A^{+}=\left\{v_{1}{ }^{+}, \ldots, v_{n}{ }^{+}\right\}\left\{\left(\max _{j} V_{i j}, i \in I\right) \mid\left(\min _{j} V_{i j}, i \in I\right)\right\} \\
& A^{-}=\left\{v_{1}^{-}, \ldots, v_{n}{ }^{-}\right\}\left\{\left(\min _{j} V_{i j}, i \in J\right) \mid\left(\max _{j} V_{i j}, i \in I\right)\right\}
\end{aligned}
$$

Where $v i+$ denotes the maximum value of $V i j$ and $v i-$ is the minimum value of $V i j . I$ is related to the benefit criteria and $J$ is associated with the cost criteria.

\subsubsection{Determination of The Closest Coefficient (Closeness Coefficient) (Ci)}

Calculation of the distance of a positive ideal solution is to use the following equation:

$$
d_{i}^{+}=\left\{\sum_{j=1}^{n}\left(v_{i j}-v_{j}^{+}\right)^{2}\right\}^{1 / 2}, i=1, \ldots m
$$

Similar to positive solutions, the separation from negative ideal solutions is written in the following equation;

$$
d_{i}^{-}=\left\{\sum_{j=1}^{n}\left(v_{i j}-v_{j}^{-}\right)^{2}\right\}^{1 / 2}, i=1, \ldots m
$$

\subsubsection{Determination of the Distance of the Positive Ideal Solution ( $d i+$ ) and the Negative Ideal Solution ( $d i^{-}$)}

The calculation of the nearest coefficient is a step used to rank each alternative. Calculation $C i$ is written in the following equation;

$$
\mathrm{C}_{1}=\frac{\mathrm{d}_{\mathrm{i}}^{-}}{\left(\mathrm{d}_{\mathrm{i}}^{+}+\mathrm{d}_{\mathrm{i}}^{-}\right)} ; \mathrm{i}=1, \ldots, \mathrm{m}
$$

Where $C i$ is the final value of an alternative in the calculation using the TOPSIS approach.

\subsubsection{Determination of the Order}

The order of value is intended to get the best solution from alternative oil and gas policies at this time. The alternative with the highest coefficient value $(C i)$ is the best choice.

\subsubsection{Sensitivity Test}

Sensitivity analysis is conducted to determine the impact of the uncertainty on the decision making model that has been made.

\section{Results and Discussion}

\subsection{Physical and Monetary Oil Balance of " $X "$ Field}

During the period of 2016-2018, the year-end petroleum reserve of the " $\mathrm{X}$ " field tends to decrease. During this period, there was an average decline of 1.07 percent per year. While in terms of production, there was an average decline of 14.31 percent per year. The average production decline from 2016, 2017 and 2018 was 9.65 percent, 25.64 percent and 7.64 percent, the sharp decline in production occurred in 2017 due to a number of technical factors occurring in the field. From this table it is also known that the ratio of reserves to production is an average of 96 , which means that oil and condensate can still be exploited for approximately 96 years assuming there are no new discoveries and constant production of 3.3 million barrels.

Table 2. Physical balance of " $X$ " field oil resources, 2016-2018 (barrels).

\begin{tabular}{llll}
\hline \multirow{2}{*}{ Details } & Year & \\
\cline { 2 - 4 } & $\mathbf{2 0 1 6}$ & $\mathbf{2 0 1 7}$ & $\mathbf{2 1 0 8}$ \\
\hline $\mathbf{( 1 )}$ & $\mathbf{( 2 )}$ & $\mathbf{( 3 )}$ & $\mathbf{( 4 )}$ \\
\hline First stock & 333.567 .026 & 329.459 .451 & 325.748 .084 \\
Stock Add. & - & - & - \\
Extraction & 4.107 .575 & 3.711 .367 & 2.759 .790 \\
Last stock & 329.459 .451 & 325.748 .084 & 322.988 .294 \\
\hline
\end{tabular}

Source: Processed Data (2019).

The calculation results show that the cost of production per unit has increased from 2016-2018. This is caused by maintenance and operation costs. After obtaining the cost of producing oil in dollars (\$) which is converted into Rupiah 
using an exchange rate of 1 USA $\$=I D R .14,000$, it is possible to carry out an economic calculation or unit rent of oil in the "X" field. Even though there is a decrease in the average Bank of Indonesia (BI) rate in 2017, the value of unit rent increases every year. The following are the results of the unit rent calculation for "X" oil field.

Table 3. Results of calculation of " $X$ " field petroleum rent (IDR / barrel)

\begin{tabular}{|c|c|c|c|}
\hline \multirow{2}{*}{ Details } & \multicolumn{3}{|l|}{ Year } \\
\hline & 2016 & 2017 & 2108 \\
\hline (1) & (2) & (3) & (4) \\
\hline Oil Price (IDR / Barrel) & 561.820 & 716.660 & 944.580 \\
\hline BI Rate (r) & $5,1 \%$ & $4,6 \%$ & $5,0 \%$ \\
\hline Lifting Cost (IDR /barrel) & 144.200 & 161.000 & 179.200 \\
\hline Oil Rent Units (IDR/Barrel) & $484.691,57$ & $607.491,61$ & $803.495,92$ \\
\hline
\end{tabular}

Source: Processed Data (2019).

Monetarily, in the 2016-2018 periods, the value of petroleum reserves has declined especially in 2018. The biggest change is due to the revaluation value. The revaluation value in 2018 is negative, indicating a relatively large price increase in that year. In addition, the production value in 2018 will be IDR. 2,217,480,047,956, so that the final petroleum stock is worth IDR. 222,655,210,375,641. In more detail, the monetary balance of oil resources can be seen in Table 4 .

Table 4. The " $X$ " field oil monetary balance, 2016-2018 (IDR).

\begin{tabular}{llll}
\hline \multirow{2}{*}{ Details } & Year & & $\mathbf{2 1 0 8}$ \\
\cline { 2 - 4 } & $\mathbf{2 0 1 6}$ & $\mathbf{2 0 1 7}$ & $\mathbf{( 4 )}$ \\
\hline $\mathbf{( 1 )}$ & $\mathbf{( 2 )}$ & $\mathbf{( 3 )}$ & 261.737 .257 .804 .412 \\
\hline First stock & 161.677 .124 .992 .395 & 200.143 .851 .849 .590 & - \\
Stock Addition & - & - & 2.217 .480 .047 .956 \\
Extraction & 1.990 .907 .022 .507 & 2.254 .624 .068 .847 & $(36.864 .567 .380 .814)$ \\
Revaluation & 40.457 .633 .879 .701 & 63.848 .030 .023 .669 & 222.655 .210 .375 .641 \\
Last stock & 200.143 .851 .849 .590 & 261.737 .257 .804 .412 & \\
\hline
\end{tabular}

Source: Processed Data (2019).

\subsection{Physical and Monetary Gas Balance of " $X$ " Field}

The physical balance of natural gas resources during the 2016-2018 periods can be seen through Table 4. In the table, natural gas reserves are constantly decreasing from 470,181,825 MSCF in 2016 to 420,745,986 MSCF in 2018. Decreasing the volume of natural gas reserves was caused by a decrease or stagnation in natural gas exploration. In addition, there were no new reserve discoveries in this time period. Thus, natural gas exploration needs to be carried out more expansively so that greater reserves are obtained. When viewed in terms of production, in the period 2016-2018, the production of natural gas in the " $\mathrm{X}$ " field has decreased by an average of 6.07 percent per year. Based on the ratio of reserves to production, it is estimated that the natural gas reserves of the "X" field can still be utilized for approximately 28 years with the assumption of constant production and new reserves have not yet been discovered.

Table 5. Physical balance sheet of " $X$ " field gas resources, 2016-2018 (Mscf).

\begin{tabular}{llll}
\hline \multirow{2}{*}{ Details } & Year & & \\
\cline { 2 - 4 } & $\mathbf{2 0 1 6}$ & $\mathbf{2 0 1 7}$ & $\mathbf{2 1 0 8}$ \\
\hline $\mathbf{( 1 )}$ & $\mathbf{( 2 )}$ & $\mathbf{( 3 )}$ & $\mathbf{( 4 )}$ \\
\hline First stock & 470.181 .825 & 451.552 .724 & 436.126 .356 \\
Stock Add. & - & - & - \\
Extraction & 18.629 .101 & 15.426 .368 & 15.380 .370 \\
Last stock & 451.552 .724 & 436.126 .356 & 420.745 .986 \\
\hline
\end{tabular}

Source: Processed Data (2019).

Every year there is an increase in the value of the unit rent due to the influence of rising prices and production costs so that it will raise the monetary value of natural gas. Calculation of natural gas rent units in the "X" field can be seen in Table 6 .

Table 6. Results of calculation of " $X$ " field natural gas rent (IDR / Mscf).

\begin{tabular}{llll}
\hline \multirow{2}{*}{ Details } & Year & \\
\cline { 2 - 3 } & $\mathbf{2 0 1 6}$ & $\mathbf{2 0 1 7}$ & $\mathbf{2 1 0 8}$ \\
\hline (1) & $\mathbf{( 2 )}$ & $\mathbf{( 3 )}$ & $\mathbf{( 4 )}$ \\
\hline Gas Prices (IDR / Mscf) & 67.200 & 75.040 & $4,6 \%$ \\
BI Rate (r) & $5,1 \%$ & 35.406 & $3,0 \%$ \\
Lifting Cost (IDR / Mscf) & 31.865 & 39.312 \\
Gas Rent Unit (IDR / Mscf) & 41.009 & 43.331 & 45.002 \\
\hline
\end{tabular}

Source: Processed Data (2019).

Monetarily, the value of the year-end natural gas inventory in 2018 is valued at IDR. 18,137,532,430,896 but received a revaluation that was negative in value indicating a loss related to holding assets (capital goods). More details for the monetary balance of natural gas resources are presented in Table 7. 
Table 7. The "X" field gas monetary balance, 2016-2018 (IDR).

\begin{tabular}{llll}
\hline \multirow{2}{*}{ Details } & \multicolumn{2}{c}{ Year } \\
\cline { 2 - 4 } & $\mathbf{2 0 1 6}$ & $\mathbf{2 0 1 7}$ & $\mathbf{2 1 0 8}$ \\
\hline $\mathbf{( 1 )}$ & $\mathbf{( 2 )}$ & $\mathbf{( 3 )}$ & $\mathbf{( 4 )}$ \\
\hline First stock & 19.281 .916 .276 .264 & 19.566 .246 .515 .614 & 19.626 .918 .706 .961 \\
Stock Addition & - & - & - \\
Extraction & 763.969 .899 .899 & 668.440 .469 .507 & 692.160 .139 .999 \\
Revaluation & 1.048 .300 .139 .249 & 729.112 .660 .854 & $(797.226 .136 .065)$ \\
Last stock & 19.566 .246 .515 .614 & 19.626 .918 .706 .961 & 18.137 .532 .430 .896 \\
\hline
\end{tabular}

Source: Processed Data (2019).

The results of this study are compared with existing research $[12,7]$ that the oil and gas resource balance sheet only calculate in general or nationally each country but is not specific to each field. Calculating the balance of each field will show which field has the most potential in the future. There are more detailed calculations from each field so that oil and gas management will be more directed to state development.

\subsection{The " $X "$ Field Oil and Gas Policy Analysis}

The "X" field has limited reserves of oil and gas resources where the field is terminated so that it can cause problems in its management if the policies implemented are not appropriate. For this reason, it is necessary to have a policy that takes into account various aspects such as economic, social and environmental (HSE). This is in the context of developing the remaining oil and gas resources in the " $\mathrm{X}$ " field so that management can take place properly and continuously to meet energy needs in the future.

This study presents the results of policy analysis using the multi criteria decision analysis method for the development of the "X" Field which has taken into account various criteria with alternative choices of oil and gas management policy models in the " $\mathrm{X}$ " field.

The criteria and alternatives used as the basis for policy making are displayed in a hierarchy presented in Figure 1.

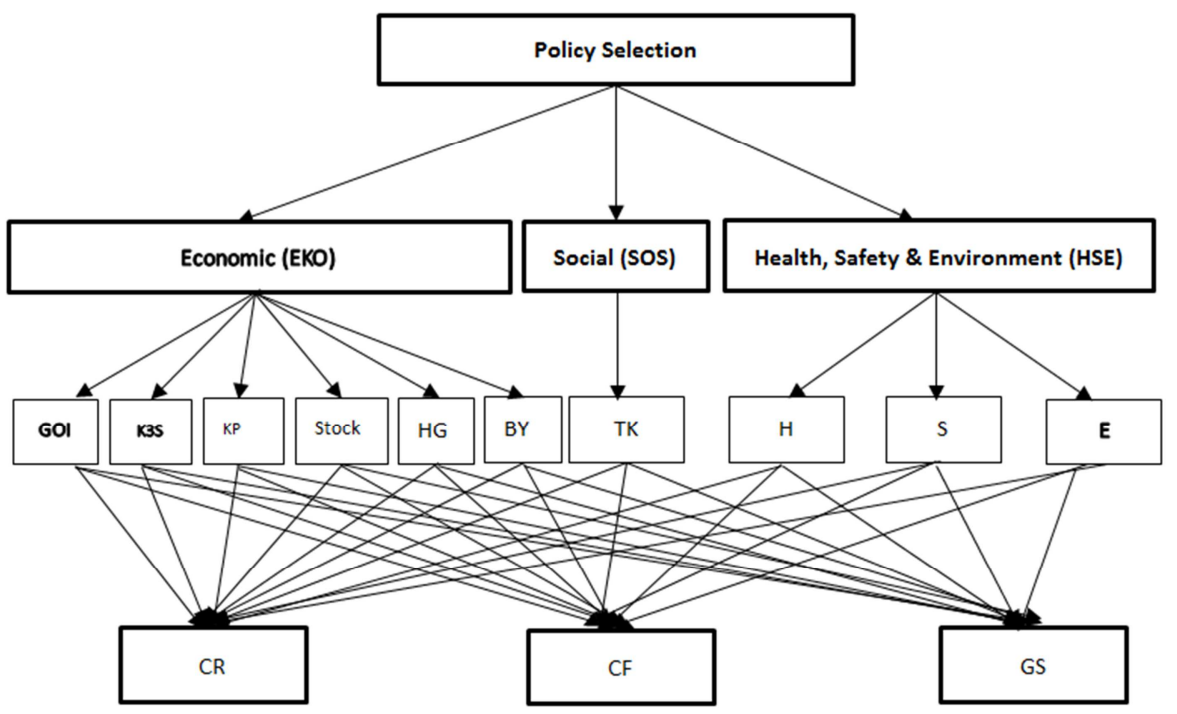

Figure 1. Hierarchy to make alternative " $X$ " field management policies.

The decision selection process to determine the best alternative oil and gas processing policies that have taken into account the Economic, Social and HSE (Health, Safety and Environmen) criteria is obtained through the following steps;

\subsubsection{Decision Matrix}

In this decision matrix, a matrix has been arranged with ten sub-criteria $(C j(j=1,2, \ldots, 10))$ which are components of the three main criteria and there are 3 alternatives (alternative $(i=1$, $2,3)$ ) alternative processing of oil and gas resources whose value will be determined. The assessment by the stakeholders is shown in Table 8.
Table 8. Policy stakeholders' assessments in weighting.

\begin{tabular}{|c|c|c|c|c|c|}
\hline \multirow[b]{2}{*}{$\begin{array}{l}\text { Sub } \\
\text { Criteria }\end{array}$} & \multicolumn{5}{|c|}{ Weight } \\
\hline & $\begin{array}{l}\text { PT. } \\
\text { CPX }\end{array}$ & KESDM & BUMN & Academic & $\begin{array}{l}\text { Average } \\
\text { Weight }\end{array}$ \\
\hline GOI & 5 & 4 & 5 & 5 & 0,120 \\
\hline K3S & 4 & 2 & 4 & 4 & 0,093 \\
\hline Stock & 5 & 4 & 5 & 5 & 0,127 \\
\hline KP\&KV & 4 & 3 & 3 & 3 & 0,087 \\
\hline HG & 4 & 5 & 4 & 4 & 0,113 \\
\hline BY & 3 & 4 & 3 & 3 & 0,087 \\
\hline TK & 3 & 5 & 3 & 3 & 0,093 \\
\hline $\mathrm{H}$ & 3 & 5 & 3 & 3 & 0,093 \\
\hline $\mathrm{S}$ & 3 & 5 & 3 & 3 & 0,093 \\
\hline E & 3 & 5 & 3 & 3 & 0,093 \\
\hline
\end{tabular}


The stakeholders consist of the government sector that represented by the Ministry of Energy and Mineral Resources (KESDM), BUMN, academics and researchers, and the company sector represented by PT. CPX where the company manages the "X" field. Each of the policy makers provides a weight assessment of each sub-criterion. The results of the decision matrix of the selection of alternative oil and gas processing policies are best presented in Table 9, 10.

Table 9. Matrix of decisions for economic criteria.

\begin{tabular}{|c|c|c|c|c|c|}
\hline \multirow{3}{*}{ ALTERNATIF } & \multicolumn{5}{|c|}{ Economic Criteria } \\
\hline & GOI & K3S & Stock & KP\&KV & HG \\
\hline & (C1) & (C2) & (C3) & (C4) & (C5) \\
\hline CR (A1) & $85^{\mathrm{a}}$ & $15^{\mathrm{a}}$ & $325748084^{\mathrm{c}}$ & $0^{\mathrm{d}}$ & $716660^{\mathrm{e}}$ \\
\hline $\mathrm{CF}$ (A2) & $63^{\mathrm{b}}$ & $37^{\mathrm{b}}$ & $322988294^{\mathrm{c}}$ & $0^{\mathrm{d}}$ & $944580^{\mathrm{e}}$ \\
\hline GS (A3) & $57^{\mathrm{a}}$ & $43^{\mathrm{a}}$ & $322988294^{c}$ & $29,64^{\mathrm{d}}$ & $944580^{\mathrm{e}}$ \\
\hline Weight (W) & 0,120 & 0,093 & 0,127 & 0,087 & 0,133 \\
\hline
\end{tabular}

Table 10. Matrix of decisions for social \& HSE criteria.

\begin{tabular}{lllll}
\hline \multirow{3}{*}{ ALTERNATIF } & \multicolumn{3}{l}{ Social Criteria } & \multicolumn{2}{l}{ HSE Criteria } \\
\cline { 2 - 5 } & TK & H & S & E \\
\cline { 2 - 5 } & $\mathbf{( C 7 )}$ & (C8) & (C9) & (C10) \\
\hline CR (A1) & $1500^{\mathrm{g}}$ & $5^{\mathrm{h}}$ & $5^{\mathrm{h}}$ & $4^{\mathrm{h}}$ \\
CF (A2) & $1500^{\mathrm{g}}$ & $5^{\mathrm{h}}$ & $4^{\mathrm{h}}$ & $4^{\mathrm{h}}$ \\
GS (A3) & $552^{\mathrm{g}}$ & $5^{\mathrm{h}}$ & $5^{\mathrm{h}}$ & $5^{\mathrm{h}}$ \\
Weight (W) & 0,093 & 0,093 & 0,093 & 0,093 \\
\hline
\end{tabular}

\subsubsection{Calculate the Normalized Decision Matrix}

The calculation for the normalized decision matrix uses Sanna Software in the analysis process. The results obtained in processing using the software are shown in Table 10. Visible changes in the nominal values contained in the column of each criterion used. This number is the result of calculation from equation 2.2.2.

Table 11. Normalized decision matrix.

\begin{tabular}{|c|c|c|c|c|c|c|c|c|c|c|}
\hline & MAX & MAX & MAX & MAX & MAX & MAX & MAX & MAX & MAX & MAX \\
\hline & GOI & KKKS & STOCK & KP \& KV & HG & BY & TKN & $\mathbf{H}$ & $\mathbf{S}$ & $\mathbf{E}$ \\
\hline 1. $\mathrm{CR}$ & 0,70728 & 0,25564 & 0,58063 & 0,00000 & 0,47275 & 1,00000 & 0,00000 & 0,57735 & 0,61546 & 0,52981 \\
\hline 2. $\mathrm{CF}$ & 0,52422 & 0,63057 & 0,57571 & 0,00000 & 0,62310 & 0,00000 & 0,00000 & 0,57735 & 0,49237 & 0,52981 \\
\hline Weights & 0,12000 & 0,09333 & 0,12667 & 0,08667 & 0,11333 & 0,08667 & 0,09333 & 0,09333 & 0,09333 & 0,09333 \\
\hline
\end{tabular}

Source: Primary data (2019).

\subsubsection{Decision of Normal Weighted Matrix}

Data calculation result to create a normal weighted matrix is shown in Table 11. The weight that has been determined from the results of interviews with key people has changed to an ideal value based on the calculation results in accordance with equation 2.2.3. The values contained in the columns in the table show the values normalized between each criterion.

Table 12. Weighted normal decision matrix.

\begin{tabular}{|c|c|c|c|c|c|c|c|c|c|c|}
\hline & MAX & MAX & MAX & MAX & MAX & MAX & MAX & MAX & MAX & MAX \\
\hline & GOI & KKKS & STOCK & KP \& KV & HG & BY & TKN & $\mathbf{H}$ & $\mathbf{S}$ & $\mathbf{E}$ \\
\hline 1. CR & 0,08487 & 0,02386 & 0,07355 & 0,00000 & 0,05358 & 0,08667 & 0,00000 & 0,05389 & 0,05744 & 0,04945 \\
\hline 2. $\mathrm{CF}$ & 0,06291 & 0,05885 & 0,07292 & 0,00000 & 0,07062 & 0,00000 & 0,00000 & 0,05389 & 0,04595 & 0,04945 \\
\hline 3. GS & 0,05692 & 0,06840 & 0,07292 & 0,08667 & 0,07062 & 0,00000 & 0,09333 & 0,05389 & 0,05744 & 0,06181 \\
\hline Weights & 0,12000 & 0,09333 & 0,12667 & 0,08667 & 0,11333 & 0,08667 & 0,09333 & 0,09333 & 0,09333 & 0,09333 \\
\hline Ideal & 0,08487 & 0,06840 & 0,07355 & 0,08667 & 0,07062 & 0,08667 & 0,09333 & 0,05389 & 0,05744 & 0,06181 \\
\hline Basal & 0,05692 & 0,02386 & 0,07292 & 0,00000 & 0,05358 & 0,00000 & 0,00000 & 0,05389 & 0,04595 & 0,04945 \\
\hline
\end{tabular}

Source: Primary data (2019).

\subsubsection{Determination of the Solution and the Distance of a Positive Ideal Solution, as Well as a Negative Ideal \\ Solution $(A+),\left(A^{-}\right),\left(d i^{+}\right),\left(d i^{-}\right)$}

The results of calculations to determine the solution and the solution distance using the Sanna program are shown in Table 12. It can be seen in the table that the value of the positive solution for GS is 0.091 and the ideal solution is negative for 0.137 . This value reflects the GS numbers in alternative GS approaching the ideal solution when compared to $\mathrm{CR}$ and $\mathrm{CF}$ and GS has the farthest distance from the negative ideal solution compared to other alternative processing policies " $\mathrm{X}$ " field.

Table 13. Distance of positive and negative ideal solutions.

\begin{tabular}{|c|c|c|c|c|c|c|c|c|c|c|c|c|}
\hline & MAX & MAX & MAX & MAX & MAX & MAX & MAX & MAX & MAX & MAX & & \\
\hline & GOI & KKKS & STOCK & KP \& KV & HG & BY & TKN & H & S & $\mathbf{E}$ & di+ & di- \\
\hline 1. CR & 0,08487 & 0,02386 & 0,07355 & 0,00000 & 0,05358 & 0,08667 & 0,00000 & 0,05389 & 0,05744 & 0,04945 & 0,13656 & 0,09179 \\
\hline 2. $\mathrm{CF}$ & 0,06291 & 0,05885 & 0,07292 & 0,00000 & 0,07062 & 0,00000 & 0,00000 & 0,05389 & 0,04595 & 0,04945 & 0,15682 & 0,03938 \\
\hline
\end{tabular}




\begin{tabular}{|c|c|c|c|c|c|c|c|c|c|c|c|c|}
\hline & MAX & MAX & MAX & MAX & MAX & MAX & MAX & MAX & MAX & MAX & & \\
\hline & GOI & KKKS & STOCK & KP \& KV & HG & BY & TKN & H & $\mathbf{S}$ & E & di+ & di- \\
\hline 3. GS & 0,05692 & 0,06840 & 0,07292 & 0,08667 & 0,07062 & 0,00000 & 0,09333 & 0,05389 & 0,05744 & 0,06181 & 0,09107 & 0,13704 \\
\hline Weights & 0,12000 & 0,09333 & 0,12667 & 0,08667 & 0,11333 & 0,08667 & 0,09333 & 0,09333 & 0,09333 & 0,09333 & & \\
\hline Ideal & 0,08487 & 0,06840 & 0,07355 & 0,08667 & 0,07062 & 0,08667 & 0,09333 & 0,05389 & 0,05744 & 0,06181 & & \\
\hline Basal & 0,05692 & 0,02386 & 0,07292 & 0,00000 & 0,05358 & 0,00000 & 0,00000 & 0,05389 & 0,04595 & 0,04945 & & \\
\hline
\end{tabular}

\subsubsection{Decision of Normal Weighted Matrix}

The closest coefficients for each alternative are presented in Figure 2 and Table 14. These coefficients are the final values calculated to determine the best order of available alternatives.
The gross split (GS) alternative is the policy alternative chosen as the best policy, followed by cost recovery $(\mathrm{CR})$ and cost and fee $(\mathrm{CF})$

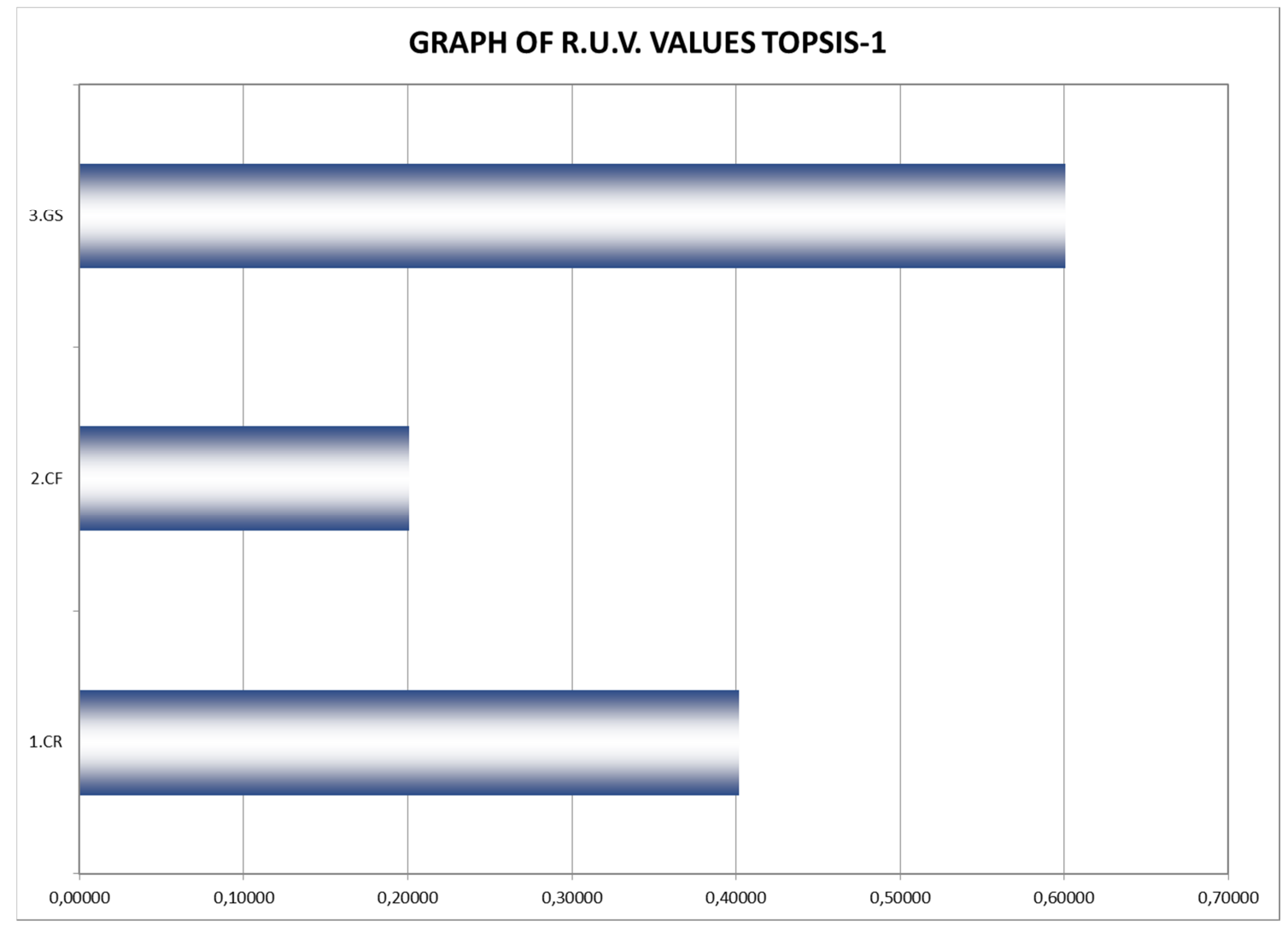

Figure 2. The "X" Field Oil and Gas Processing Policy Chart based.

Table 14. The coefficients closest to alternative policies in the " $X$ "field.

\begin{tabular}{lll}
\hline Ranking & Alternative & R. U. V \\
\hline 1 & 3. GS & 0,6008 \\
2 & 1. CR & 0,4020 \\
3 & $2 . \mathrm{CF}$ & 0,2007 \\
\hline
\end{tabular}

Source: Primary data (2019).

The alternative composition of the " $\mathrm{X}$ " field processing policy is that if the government wants to apply the business as usual development model with key person weights and equals, the oil and gas field development options are GS, CR and CF. Changes in prices and costs in each alternative and weight criteria according to the results of the key person (HG-BY + $\mathrm{KP}$ ) and equal rate (HG-BY $+\mathrm{ER})$ results in the choice of GS being the first choice.

Table 15. Results of calculating the nearest coefficient and sensitivity test.

\begin{tabular}{llll}
\hline \multirow{2}{*}{ Alternative } & Sensitivity Test & \\
\cline { 2 - 4 } & BAU + KP & BAU +ER & HG-BY +KP \\
\hline GS & 0,6008 & 0,5954 & 0,5987 \\
CR & 0,4020 & 0,4071 & 0,4041 \\
CF & 0,2007 & 0,1884 & 0,1846 \\
\hline
\end{tabular}

Description; $\mathrm{BAU}+\mathrm{KP}$ : price and cost according to business as usual (BAU) and weight according to key person; $\mathrm{BAU}+\mathrm{ER}$ : price and cost according to business as usual
(BAU) and weight according to equal rates; HG-BY + K. P: price according to ICP price change, cost according to field cost "X" economic weight according to key person; HG-BY + 
E. R: prices are in accordance with changes in ICP (Indonesia Crude Price), costs are according to field costs " $\mathrm{X}$ " field economic weights according to equal rates.

\section{Conclusion}

Reserves proven to be in the " $\mathrm{X}$ " field at the end of assessment date 2018 show the physical balance of oil of $322,988,294$ barrels with an oil monetary balance of IDR $222,655,210,375,641$ while the physical gas balance of $420,745,986$ Mscf with a monetary value of gas of IDR $18,137,532,430.896$.

An alternative order of management policies so that the utilization of the remaining oil and gas resources is more optimal by considering economic, social and HSE (Health, Safety and Environment) criteria in the " $\mathrm{X}$ " field are Gross Split (GS), Cost Recovery (CR) policies and Cost and Fee (CF) policy.

\section{Suggestion}

Calculation of the physical value of oil and gas reserves should be done on the entire oil and gas field reservoir system, with more attention to the level of uncertainty of the parameters in the technical calculation methods so that the physical value of the resulting reserves is more accurate.

The calculation of the economic value of oil and gas reserves should not only be limited to financial calculations but also consider the externalities generated from mining activities.

Further studies need to be carried out on wealth management policies controlled by the state, especially related to oil and gas. Management of oil and gas resources is not only limited to administration, but analysis needs to be done on policies that can optimize the management of oil and gas resource assets until sustainable development is achieved.

\section{References}

[1] Belmazouzi, Y \& et al. Contribution to the ageing control of onshore oil and gas fields. 2019. LRPI Laboratory, Institute of Health and Safety - University of Batna. Algeria.

[2] Bergh VDJ. Handbook of Environmental and Resource Economics. 1999. Massachusetts: Edward Elgar Publishing, Inc.

[3] Cooper, D. R., Schindler, P. S. Business Research Methods 12th Edition. 2014. McGraw-Hill. United States.

[4] Decree of the Minister of Finance. The Strategy and Policy Guidelines of the Ministry of Finance. 2005. Number: 464 KMK. 01 / 2005. Jakarta.

[5] Decree of the Minister of Finance. Organization and Work Procedures of the Ministry of Finance. 2006. Number: $466 /$ KMK. 01 / 2006. Jakarta.

[6] Decree of the Minister of Finance. Blueprint of the Ministry of Finance's Institutional Transformation Program 2014-2025. 2014. Number: 36 / KMK. 01 / 2014. Jakarta.
[7] E. Veldhuizen and et al. Valuation of Oil and Gas Reserves in Netherlands 1990-2005. 2009. Statistics Netherlands Discussion Paper (09029).

[8] Fauzi, A. Natural Resources Economic \& Environment. Theory and Application. 2006. PT. Gramedia Pustaka Utama. Jakarta.

[9] Grundy, B. D., and Heaney, R. Valuation of Crude Oil and Gas Reserves. 2008. SSRN-id1966829.

[10] Howes, J. V. C.. Petroleum resources and petroleum systems of SE Asia, Australia, Papua New Guinea, and New Zealand. 1997. Proceedings of an International Conference on Petroleum Systems of SE Asia \& Australasia: Indonesian Petroleum Association, p. 81-100.

[11] Höök, M. Depletion and Decline Curve Analysis in Crude Oil Production. 2009. Global Energy Systems Department for Physics and Astronomy, Uppsala University.

[12] Jafari, Y \& Othman, J. Accounting for Depletion of Oil and Gas Resources in Malaysia. 2011. National University of Malaysia. Malaysia.

[13] Kadir, A \& Suzandi, E. Alternative Models of Oil and Gas Cooperation Contracts. National Symposium on the Indonesian Petroleum Engineering Association (IATMI) 2005. Bandung.

[14] Kahraman C. Fuzzy Multi-Criteria Decision-Making: Theory and Applications with Recent Developments. 2008. New York: Springer.

[15] Khojastehmehr, M \& et al. Screening of enhanced oil recovery techniques for Iranian oil reservoirs using TOPSIS algorithm. 2019. Energy Reports 5 (2019) 529-544. Elsevier Ltd.

[16] Liana, L. Using Analytical Hierarchy Process to Determine Approriate Minimum Attractive Rate of Return for Oil and Gas Project in Indonesia. 2014. PM World Jurnal Volume III, Issue II.

[17] Magoon, LB and Dow, W. G. The Petroleum System-from Sources on Trap. 1994. AAPG Memoir 60. USA.

[18] Masyitoh, OC. Assessment of Oil and Gas Reserves as Wealth Under the State of Study in the "Sranta" Field. 2016. Gajah Mada University. Yogyakarta.

[19] Ministry of Energy and Mineral Resources [KESDM]. Regulation of the Minister of Energy and Mineral Resources. 2017. Number 082017 concerning Gross Split Revenue Sharing Contracts. Jakarta.

[20] Ministry of Energy and Mineral Resources [KESDM]. Regulation of the Minister of Energy and Mineral Resources. 2017. Number 522017 concerning Amendment to the Regulation of the Minister of Energy and Mineral Resources Number 082017 concerning Gross Split Production Sharing Contract. Jakarta.

[21] Ministry of Energy and Mineral Resources [KESDM]. Handbook of Energy \& Economic Statistics of Indonesia. 2018. Jakarta (ID).

[22] Perman, $\mathrm{R}$ and et all. "Natural Resource and Environment Economics". 2002. Vol. 3rd Edition. Essex, UK: Pearson Education Limited.

[23] Pickles, E., and Smith, J. L. Petroleum Property Valuation: A Binomial Lattice Implementation of Option Pricing Theory. 1993. The Energy Journal, Vol 14, No 2. IAEE. United States. 
[24] Private, A. Z. 2012. Investment Valuation in Comparative Drilling Wells of DCF and Real Option Methods in the Sanga-Sanga Block (Study on VICO Indonesia). Unpublished thesis. Postgraduate Program at Gadjah Mada University, Yogyakarta.

[25] Raheditya, R. Analysis of Investment Project Decision on the Installation of Compressor Booster as an Effort to Maintain the Production of Natural Gas Offshore 1-Parigi in PT. PEP with AHP and Topsis Method. 2016. ITS. Surabaya.

[26] Schreyer, P. and C. Obst, 'Towards Complete Balance Sheets in the National Accounts: The Case of Mineral and Energy Resources'. 2015. OECD Green Growth Papers, No. 2015/02, OECD Publishing, Paris.

[27] SKK Migas. Annual Report 2016. 2016. Jakarta.

[28] SKK Migas. Work Procedure Guidelines. PTK-037. 2018. Jakarta
[29] Society of Petroleum Engineers dan World Petroleum Council. Petroleum Resources Management System. 2007. World Petroleum Council.

[30] Suparmoko, M., Sudirman, D., Setyarko, Y., and Wibowo, H. S Economic and Natural Resource Economic. 2014. Valuation First Edition. BPFE. Yogyakarta.

[31] Tampubolon, B. Analysis of Geothermal Energy Utilization Policy as Alternative Power Generation. 2015. Bogor Agricultural University Postgraduate School. Bogor.

[32] Virine, L., Murphy, D. Analysis of Multi-Criteria Decision Making Methodologies for the Petroleum Industry. 2007. IPTC 11765, International Petroleum Technology Conference, 4-6 December 2007, Dubai.

[33] Wang TC, Lee HD. Developing a Fuzzy TOPSIS Approach Based on Subjective Weights and Objective Weights. 2009. Expert System with Applications. 36 (2009): 8980-8985. Elsevier Ltd. 